\title{
A CONCEPT ANALYSIS OF NURSES' COMMITMENT TO PATIENT CARE
}

\section{J.N. Mekwa, L.R. Uys and M.V. Vermaak}

\begin{abstract}
Commitment to the service of mankind has always been a key concept of professional nursing. However, very little effort seems to have been made to analyse the nature of commitment as a factor in nursing.
\end{abstract}

This article explores the meaning of the concept 'commitment' as revealed by a review of the literature and the responses of a group of registered nurses in unsiructured interviews. It goes on to analyse the concept by means of a number of techuiques such as an analysis of critical attributes, the construction of model cases and related cases, the identification of antecedents and consequences and of empirical referents.

The information gleaned was used to structure a study of the commitment to patient care of a group of professional nurses which will be published in a subsequent article.

\section{Opsomming}

Verbintenis tot diens aan die mensdom was nog altyd 'n sleutelkonsep van professionele verpleging. Daar is egter skynbaar tot duster mill gedoen om die aard van verbintenis tot pasiëntsorg as faktor in verpleging te analiseer.

In hierdie arlikel word die betekenis van die konsep verbintenis verken soos dit deur 'n literatuurstudie en die response van 'n groep geregistreerde verpleegkundiges tydens ongestruktureerde onderhoude blootgelê is. Verder word die konsep met behulp van 'n aanial tegnieke geanaliseer, naamlik 'n analise van kitiese eienskappe, die konstruksie van model. en verwante gevalle, die identifikasie van autesedente en gevolge, envan empiriese verwysings.

Die inligting wat verkry is, is gebruik om 'n studie van die verbintenis tor pasiëntsorg van 'n groep professionele verpleeglandiges te struktureer. Hierdie nanorsing sal in ' $n$ volgende arrikel gepubliseer word.

\section{STATEMENT OF TIIE PROBLEM}

\section{INTRODUCTION}

Since its inception, professional nursing has declared in no uncertain terms the need for commitment to the service of mankind by the nurse practitioner. This, according to Searle, Brink and Beukes (1983) is evidenced by the wealth of nursing literature devoted to the enhancement of the image of the profession and the promotion of the quality of nursing care. In a well-intended effort to achieve this purpose, much energy has been expended with the result that commitment as a concept has become almost a household word in professional nursing circles. However, very little effort has bcen made to analyse the nature of commitment as a factor in nursing. This has led to the matter-of-fact use of the concept and its consequent ambiguity and loss of meaning.

Various authors in the profession agree that the use of ambiguous language by a profession indicates scientific weakness (Rogers 1971, 85). It spells failure on the part of the profession to identify its uniqueness. It is thus argued that the extent to which the nursing profession can succeed in meeting its multi-faceted responsibilities depends, among others things, on its ability to clarify with reasonable accuracy the meanings and significance of all traditional ideologies on which it has been founded. This is particularly so when one considers the need for professional nursing to hold its own among other professions. It is pointed out by many nurse leaders that for its healthy and stable growth, the profession can least afford to discard its values (Searle 1968; Czmowski 1974). New discoveries should be used to reinforce their valid precursors, and together they should be used to structure new concrete foundations. Parallels and convergencies should be identified. Complacency on the part of professionals regarding loss of values only creates uncertainty and conflict and at best, passivity with all its undersi rable consequences.

Ethical parallels and convergencies need to be identified in order to solidify the matrix of the character of professional nursing.

\section{Lack of Commitment}

Commitment is identified by several nurse leaders as a central pivot from which care emerges. Bevis (1982) states that the quality of nursing care depends upon the quality of those giving care. Searle et al. (1983) among others, submit that commitment has a definite positive influence on the quality of nursing care. Emphasizing the need for professional nurses to internalize certain values in respect of patient care, Searle et al. (1983) write, "This transformation and outlook engenders the sense of commitment with which nursing educators and nursing practitioners are concerned and which is the essence of the profession's service to mankind". Whilst this is so, it is impossible to overlook the growing concern pertinent to an apparent lack of professional commitment among nurses as a whole. Such statements as the ones that follow are an indication of this concern. "There are numerous signs that we are beginning to lose sympathy and compassion which have so long characterized nursing ...Nurses are becoming increasingly afflicled by the unrelatedness, alienation and lack of commitment so prevalent today" (Travelbee $1971,2)$, and Fromer $(1981, x i)$ states "Somewhere along the line after graduation these concerns and values become lost or at least are repressed enough that they are no longer present at a conscious level in professional functioning. Many nurses have been described as uncaring, insensitive, and hardened to the needs of their clients". Statements such as these show concern about the lack of commitment evidenced by nurses.

Lack of Clarity and Research

According to the researcher's observations, there seems to be no indication of any studies 
conducted on the subject of commitment. In the limited available literature, the inference made on commitment as a factor in nursing lacks specificity regarding the nature and measurement of commitment as a phenomenon. Content derived from nursing authors such as Travelbee (1971) and Auld and Birum (1973) whose works on commitment are based on the philosophical writings of Marcel, al though very valuable, serve no useful purpose towards dispelling the uncertainty surrounding commitment in the nursing context. If commitment is so vital to nursing practice that it forms its very essence, it is imperative that the uncertainty be dispelled and the meaning of the concept be clarified for the benefit of all concerned. The discovery of facts about phenomena such as commitment will help in eliminating weaknesses in the conceptual structure of nursing practice. It is proposed here that the need to clarify the meaning and criteria for commitment as a concept in the professional nursing context is long overdue.

\section{AIMS OF THE STUDY}

Although the interest in this study was triggered by allegations that there was lack of commitment among nurses, its aim is not directly concemed with the question of whether or not the allegation is true. Instead, on the basis of the problems mentioned earlier, the study was undertaken to:

* clarify the theoretical meaning of the concept "commitment to patient care",

- determine the functional meaning and importance of commitment in the work situation of the registered nurses in Bophutatswana,

- to identify factors/behaviours that manifest the nurses' commitment to patient care.

Only the clarification of the theoretical meaning of the concept in the nursing context is discussed in this article.

The researcher points out that although in common practice the term 'commitment' is used unqualified (as in the statement 'commitment is the essence of the profession's service to mankind'), to achieve specificity in this study, the concept 'commitment to patient care' is used instead. Again, whilst the researcher shares with Travelbee (1971) the view that nursing care encompasses a wide variety of activities directed at the health needs of individuals, sick or well, including the family and the community, the concept nursing care or patient care is used to refer to the care of persons encountered in health care institutions only. In the context of this study therefore, patient care is used to refer to all measures undertaken by the nurse in meeting the health care needs of those in health care institutions, irrespective of the reason for their being there.

\section{ANALYSIS OF TIIE CONCEIT 'COMMITMENT TO PATIENT CARE'}

\section{INTRODUCTION}

Since one of the aims of this study was to remedy or reduce the apparent lack of clarity about the meaning of the concept commitment in the nursing context, an analysis of the concept was undertaken. In order to do this the researcher combined the approaches suggested by Chinn and Jacobs (1983) and Walker and Avant (1983). Whereas the former identify five steps of this process, viz:

- identifying the concept;

- examining existing definitions of the word label;

- constructing cases;

* testing cases, and

- formulating criteria,

the latter suggest eight steps as follows:

- selecting a concept;

* determining the aims and purpose of analysis;

- identifying all uses of the concept that can be discovered:

- constructing a model case;

- constructing additional cases;

- identifying antecedents and consequences;

- defining empirical referents.

- An examination of these steps revealed that except for categorization groups and terminology differences, the two approaches basically were identical.

\section{APPROACII}

\section{Existing definitions of 'Commitment'}

Some dictionary definitions

The Heineman English Dictionary defines the verb 'to commit' as:

- "to do, to perform, e.g. he is likely to commit a serious crime;

- to give, to put into trust or charge of; e.g. it is possible to commit the whole responsibility to one person; he will commit the combination code to memory;

- to pledge or bind; e.g. he did not commit himself to undertaking all the tasks his dying mother assigned him."

Commitment therefore means: the act of committing; the state of being committed; a promise to do something. The Pocket Oxford Dictionary defines the verb 'to commit' as:
- "to entrust or consign for treatment or safe keeping;

* to put or throw in (to the earth, the flames etc.);

- to send (person) to prison;

- to be a doer of (blunder, crime etc.);

- to expose to risk;

- to involve in a course of action;

* to pledge or dedicate oneself (10 a course of action etc.)."

Being committed means being dedicated to or involved with a particular doctrine, course of action, etc. Commitment as a noun means an undertaking or pledge that restricts freedom of action; dedication to or involvement with a particular doctrine, course of action etc.

Commitment is therefore:

* the act or process of entrusting or consigning for safe keeping;

- an act of engagement or pledging;

- in law - a warrant for imprisonment; also the state of being committed or act of committing to prison.

Definitions given by registered nurses Bophuthatswana

Some of the definitions of the concept commitment extracted from the responses made by nine registered nurses in Bophuthatswana who took part in the pilot study, are given below: (The nurses in the pilot study were chosen at random from the staff of the Bophelong Community Hospital in Bophutatswana and interviewed in their working situations in the medical, surgical, paediatric and intensive care wards)

- it involves independence to know more, and doing what you have to do with concern and it has a goal. It goes out and it produces something good, i.e. the results are visible;

- being held up, like for example if I get an offer for a trip and refuse because I have other things to do;

- it implies that I have a duty or responsibility;

- for example when a woman is in the second stage of labour, knowledge that she should not be left alone until she has delivered implies commitment;

* I see commitment as an obligation. What one is expected by oneself to do. It's sort of responsibility. Something that you cannot run away from, something that you have to account for;

- it means you must do everything you know to the best of your ability ... nobody is forcing 
you to do it, but you do it because you want to. It is voluntary;

* it involves to feel responsible in your position just like being a mother who is committed to play her role as a mother to her family;

* you must feel that the working situation is part of you and not dissociated from your daily life;

- it depends on the liking to be committed, for example, an individual who just works to earn a living is not committed. It depends on the personality of the individual;

* commitment means not fully involved in a sphere. Not much responsibility; whereas in involvement there is full responsibility. It involves creativity and initiative. It means giving out something, for example in studies, the time spent, the search for information, the sacrifice, all call for involvement.

* commitment might be a result of obligation;

- commitment lacks strong intrinsic motivation, that is if I am right;

- making a promise that I must fulfil - a promise that I make to somebody or myself;

held up by certain important matters which might prevent you from carrying out certain issues which need immediate attention.

\section{Critical Attributes}

This step is termed by Chinn and Jacobs (1983) as 'formulating the criteria'. They further state that criteria specify the necessary and sufficient conditions for the concept to exist. These criteria should express adequately both the qualitative and the quantitative aspects of the phenomenon. In addition "criteria will not precisely define the concept but rather will provide guidelines for determining whether or not the reality basis for the concept exists in a given situation" (Ibid, p87). Walker and Avant (1983) term this stage as the determination of definition or critical attributes. Acccording to these authors this stage comprises a list of characteristics which help to identify the occurrence of a specific phenomenon as differentiated from another similar or related one; furthermore, when all the instances of a concept have been gathered, the decision as to which meanings will be most useful in relation to the aims of the analysis rests with the analysts. The decision is influenced by consideration of the social or nursing context in which the concept is to be used.

In analysing the definitions obtained from the consulted dictionaries and the pilot study, the following critical attributes were identified in respect of the meaning of the concept 'commitment':

* active and purposeful involvement with or participation in a chosen cause;
* unlimited freedom in the choice of cause with limitation of freedom due to the demands of the cause, i.e. limited freedom within unlimited freedom;

- voluntary indebtedness to and protection of others;

* selflessness;

- action and active participation;

* willingness to be part of the cause.

In the case of the nurse being committed to patient care:

* she makes a free choice to become involved in the cause of patient care;

* her involvement is unconditional and unreserved;

- she is convinced of the good of serving human beings for their own sake;

- her measures of care are primarily intended for the benefit of the client on whom she does not impose her choices or decisions;

* she accepts full responsibility for her undertakings in patient care.

\section{Constructing Cases}

According to Chinn and Jacobs (1983), once existing definitions of the concept have been listed, various cases for testing ideas thought to be embodied in definitions of the concept must be constructed. From these cases tentative criteria for the concept under study begin to emerge. The following cases were constructed:

\section{A Model Case}

A model case is a "real" life example of the use of the concept. It includes all critical attributes to the best of the analyst's present understanding of the concept. The impressions derived from the model case may be clearly evident in the description or may be implied by the behaviours that are described. "Basically, the model case is one which we are absolutely sure is an instance of the concept" (Walker \& Avant 1983: 31).

\section{Example}

Five minutes before lunch time, just as she completes her ward round, Miss More, a registered nurse, spots $\mathrm{Mr}$ Xulu, a convict who has been in a coma for the past twenty one days, blinking. Although she cannot believe her eyes she exclaims for joy. She comes closer with the hope of seeing Mr Xulu blink again. She gently strokes his arm, at the same time urging him to respond. Mr Xulu, however, just lies still. Because the response means so much to her, Miss More decides to wait a little longer at the bedside. After several attempts to get Mr Xulu to respond, Miss More notices that lunch time is over and the ward doctor has arrived for rounds. She just cannot wait to tell the doctor and her colleagues how rewarded she feels about the improvement in Mr Xulu's condition. She maintains that it is not her effort alone but that of the whole staff that has helped Mr Xulu. She works with even more dedication to ensure $\mathrm{Mr}$ Xulu's continued improvement.

\section{A Contrary Case}

A contrary case is one that is certainly not an instance of the concept being analysed. It may be related enough to be similar in some respects but is is definitely not representative of the concept. By comparing the differences between instances of the model and contrary cases, one is able to revise, add to, or delete from the tentative list of criteria being formulated for the concept.

\section{Example}

On completion of her educational programme, Lindi, now a registered nurse, applies for four different jobs, only one of which is in nursing. All four places offer her employment with immediate effect. In each case she studies the conditions of service thoroughly, comparing the benefits. She ultimately decides to take up the nursing post because compared with the others, it offers better benefits.

\section{A Borderline Case}

A borderline case is an instance which contains some, but not all of the critical attributes of the concept being examined. According to Walker and Avant (1983) a borderline case even may contain most or all of the criteria but differs substantially in one of them, such as the length of time or intensity of occurrence. Chinn and Jacobs (1983) describe a borderline case as an instance of pseudo- or metaphorical application of the word label under scrutiny; it which comes about as a result of the need for the evolution of language and thought to represent new phenomena having no available word to describe them. A special feature of borderline cases is that limitations of the central meaning imposed by examining such cases do not inhibit the new usage, but rather a critical one or two features of the concept's core meaning may become prominent.

\section{Example}

"I have realised that nursing is not my line but I have to go on since I have already committed myself", remarked a dissatisfied student nurse.

\section{Related Cases}

The construction of related cases is regarded as one of the most productive approaches used in concept analysis. It involves the examination of differences between concepts intimately related to the study concept, but which are thought not to mean exactly the same. Construction of related cases helps us understand how the concept under study fits into the network of associated concepts.

The following concepts have been identified as those related to the concept of commitment:

\section{Loyalty}

The term loyalty is an abstract noun derived from the term loyal. The Oxford Paperback Dictionary (1984) defines it as "steadfast in 
one's allegiance to a person or cause or to one's country or sovereign", while Longman's Dictionary of Contemporary English defines loyalty as "a connection which binds a person to someone or something to which he is loyal".

From these definitions it is clear that loyalty resembles commitment in certain aspects, for instance, they both involve attachment, or a bond of a steadfast and continued nature. However, it differs from commitment in that it is discriminatory: it is accorded only to those who are held in esteem - those who are regarded as symbols of power. The relationship governed by loyalty lacks reciprocity in that the disadvantaged party is duty-bound to serve the advantaged party. In contrast to commitment loyalty significantly benefits those in power.

\section{Dedication}

Dedication is described in the Heineman English Dictionary as "a state of being wholly devoted to something". Devotion is explained as "a strong love or affection".

This means that in contrast to loyalty, devotion is characterised by love, affection and admiration which makes devotion and dedication somehow similar. Dedication seems to differ from commitment in that whilst a dedicated person gives wholly or completely to someone or something, involvement of the self is not indicated. In the case of dedication the beneficiary is usually not at risk, but in an advantaged position because he revered. Dedication therefore, is also single-directional.

\section{Motivation}

Motivation is a concept derived from the term 'motive' which is described by behaviourists as a causative factor, the impelling force or energy behind an individual's goal-directed behaviour. Because it is goal-directed, once the goal has been realised and satisfaction reached, the goal-seeking behaviour ceases. Motivation therefore differs from commitment in that it is intended for the satisfaction and benefit of the self.

\section{Duty}

The term duty is explained as a "moral or legal obligation, what one is bound or ought to do, binding force of what is right" in the Pocket Oxford Dictionary (1984 p.229), and "what a person is obliged or feels obliged, to do" in the Heinemann English Dictionary (1979 p.334). The concept duty, therefore, implies an obligation which can be legally enforced. Duty overrides the individual's freedom of choice and has legal implications while commitment has none.

Fromer (1981 29) expresses the view that "... duty must play a role in professional commitment and is part of the desire to help and serve clients. The point of view suggests that commitment is part of duty, but not the whole of it.

\section{A llypothetical Case}

An invented or hypothetical case is one which is constructed using ideas outside one's own experience. The use of an invented case when examining a very familiar concept or one which is such a 'commonplace' as to be taken for granted, is recommended by Walker and Avant (1983). In order to get a true picture of the critical defining attributes of such concepts they suggest that the concept be taken out of its ordinary context and put into an invented one. The example below illustrates commitment:

\section{Example}

An isolated, primitive island was struck by a leprosy epidemic. Eventually all the inhabitants were affected and there was nobody left to care for anybody. A new scientific gadget was invented that emitted rays which would destroy the causative organism. But this meant that someone who had never been exposed to the infection would have to haul the gadget the length of the island within a specified period to escape infection, dump it with its dangerous contents into the sea and swim to safety.

Because of the risks involved whoever undertook the mission had to understand the implications and accept the task willingly without undue persuasion. A certain Dr. Bongani volunteered, saying that he was convinced that it was his responsibility as a human being to help his fellow-beings and that he believed it was a worthy task. He took all necessary measures to avoid danger to himself and successfully accomplished the mission.

Chinn and Jacobs (1983) state that there are other varieties of cases which may be useful in analysing concepts. "How cases are classified is not critical, but their important function in stimulating clarity of meaning is extremely significant" (Ibid, p86). It was on such grounds that the research decided to use concept analysis for the present study.

\section{Identifying antecedents and consequences}

Antecedents are those events or incidents which must occur prior to the occurrence of the concept. Consequences are those events or incidents which occur as a result of the occurrence of the concept. The determination of these two elements is recommended by Walker and Avant (1983) on the grounds that it may shed considerable light on the social context in which the concept is generally used. It also becomes helpful in further refining the critical attributes of the concept under study.

\section{Antecedents for commitment to patient care:}

(i) conviction that humans are worthy beings;

(ii) development of genuine love and respect for human beings;

(iii)ability to transcend the self in patient care interventions;

(iv) conviction that human life has purpose and meaning;

(v) willingness to contribute in a meaningful way towards the welfare of one's fellow beings.

\section{Consequences of Committment:}

(i) openness and accessibility to patients in times of need:

(ii) ability to find fulfilment of life's purpose in patient care interventions;

(iii)therapeutic use of self;

(iv)personal and professional growth of the nurse.

\section{Empirical Referents}

According to Walker and Avant (1983:34) empirical referents are "classes or categories of actual phenomena which by their existence or presence demonstrate the occurrence of the concept under study". They point out that in many cases the critical attributes of the concept and the empirical referents are identical. However, when the concept being analysed is highly abstract, the critical attributes are also abstract. This necessitates the determination of the empirical referents.

In the case of commitment to patient care the following empirical referents were identified by the researcher:

(i) Overt preparedness and willingness by the nurse to go that bit further to do for the patient that much more than that to which she is legally bound.

(ii) Verbalizing the need for committed care in both formal and informal situations.

(iii)Speaking positively about patients and patient care at all times even during times that are most exerting.

(iv) Providing consistently and unconditionally for the needs of patients even when confronted with adverse situations.

(v) Spontaneous or voluntary involvement in activities that promote commitment to patient care in both small and large scales.

(vi) Showing respect to all patients and their rights without discrimination.

\section{CONCLUSION}

The term commitment was found to have a variety of meanings, one of which is the meaning related to commitment to patient care. In this context it is a state of being which influences the quality of the nurse-patient relationship. It draws the nurse and the patient logether and is a disciplined way of approaching patient care and its problems. Although most of the nurses interviewed attached the same 
meaning to the term as that concluded by the researcher, some held different views.

This article is based on part of the research undertaken by the first author in 1990 for the degree M.Soc.Sc.(Nursing) at the University of the Orange Free State.

\section{REFERENCES}

AULD, M.E. AND BIRUM, L.H. (1973). The challenge of nursing - a book of readings, Saint Louis: C.V. Mosby.

BEVIS, E.M.O. (1982). Curriculum Building in Nursing - A Process, Saint Louis: C.V. Mosby.

CHINN, P.L. AND JACOBS, M.K. (1983). Theory and nursing - a systematic approach, St. Louis: C.V. Mosby.
CZMOWSKI, M. (1974). Value Teaching in Nursing, Nursing Forum, Vol.xiii, No.2, pp.192-206, Philadelphia, Nursecom.

FROMER, M.J. (1981). Ethical Issues in Health Care, Saint Louis, Toronto, London: C.V. Mosby.

ROGERS, M.E. (1971). An Introduction to the Theoretical Basis of Nursing, 2nd ed. New York: F.A. Davis.

SEARLE, C. (1968). A South African Credo, Pretoria: South African Nursing Association.

SEARLE, C. BRINK, H. AND BEUKES, $M$. (1983). Nursing education guide, NUE 301-E/1, Pretoria: University of South Africa.

TRAVELBEE, J. (1971). Interpersonal Aspects of Nursing, Philadelphia: F.A. Davis.
WALKER, L.O. AND AVANT, K.C. (1983). Strategies for theory construction in nursing. Norwalk: Appleton Century Crofts.

\section{DICTIONARIES}

Longman's Dictionary of Contemporary English (1980), Bath: Pitman. 3rd impression.

The Pocket Oxford Dictionary of Current English (1983), Oxford University Press: 6th edition.

JN. Mekwa, M.Sac.Sc.(Nursing) (U.O.F.S)
Lecturer, Department of Nursing, University
of Bophuthatswana
L.R. Uys, D.Soc.Sc.(Nursing) (U.O.F.S)
Professor and Head, Department of Nursing,
University of Natal
M.V. Vernaak, M.Soc.Sc. (Nursing) (U.O.F.S)
Senior Lecturer, Department of Nursing,
University of the Orange Free State

